\title{
DIGITAL EDUCATION: OPPORTUNITIES, THREATS, AND CHALLENGES
}

\author{
Muhammmad \\ Muhammad Suleiman'; \\ Bilkisu Gambo \\ Danmuchikwali ${ }^{2}$
}

Department of Home \& Rural Economics, School of Rural \& Entrepreneurship

Development, Rano, Kano State Polytechnic, Nigeria

Alamat Korespondensi muhddkd@gmail.com:; bilkisugsheshe9@gmail.com ${ }^{2}$

\begin{abstract}
Digital education is largely an innovation of the last few decades, although it already existed in various forms slightly earlier. Shortly, the educational system environments are anticipated as mitigation to unforeseen natural and artificial pandemics such as Covid- 19 in 2020 by the significant changes associated with the digitalization of some portion of the system. This article aims to provide valuable perspectives of ICT and digital education into its future benefits, risks, and challenges of embracing the latest technologies in the digital era, and vast online open courses. We have checked a profound change in the way we interact and generate within the academics with the advent of internet technologies. Globally, the digital revolution favoured open access to information. Classrooms today have a lot of ICT resources nearly all the teachers have made great strides to incorporate digital technology to increase access to information and collaborative activities for the learners.

Keywords: Digital Education; ICT; Online; E-Learning; Virtual Learning
\end{abstract}

\section{INTRODUCTION}

Digital education is largely a result of the past few years, though it has already existed slightly earlier in various ways. It is obvious; however, that modern equipment and means of transmitting information are important for its growth. Thus, without the rapid development of computers and the Internet, this form of education would not be feasible. It can be inferred that they were primarily concerning digital education and somehow forced its advent because the proliferation of computers and broadband Internet gave a very strong impetus to use them in educational activities as well (Makosa, 2014). Consequently, interactive classes, modern e-learning courses, educational games, electronic assessments, educational resource portals, digital school registers, and learning process management systems have entered into daily existence today. This article aims to illustrate the context of digital education, the current state of its implementation, the anticipated outcomes, and concerns in this regard. The re-election here will culminate in the presentation of the viewpoints for interactive coursebooks (Makosa, 20l4).

Three related items in education are made possible by digital technologies: teaching without physical contact, immersive practice, and contact on-site. Clickers were an early device to improve interaction in class, but now the pervasiveness of smartphones enables students to use these devices as an alternative medium of contact with teachers and between students. We will clarify how to use top content produced for MOOCs to enhance on-campus classes, where a key added feature is personal interaction (Delgado Kloos et al., 2017).

The provision of electronic or digital educational facilities is known as e-learning. This involves materials for studying, preparation, knowledge transfer, etc. The successful implementation of e-learning is achieved with the aid of technology, modern pedagogies, degree of instructor and facilitator participation, quality of the programs, and other demographic factors. This article discusses the opportunities, threats, and challenges involved in delivering digital education (Department for Education, 2019), (Naresh \& Rajalakshmi M., 2017). Tools will continuously play an essential part in motivating institutions of higher education. To this end, educational practitioners, faculty, staff and administrators must counter academic integrity, human rights, and intellectual property concerns that have become a major concern in the educational environment (Delgado Kloos et al., 2017), (Cohen, 2009), (Habiburrahim, 2015). 
It is unquestionable that, as we experience a rapid technology transition and reach a new millennium, new technologies have given instruments for reconstructing education. In particular, interactive technologies such as CDROMs, the Internet, and the Web create countless new tools and materials for educational expansion. The information and communication technology (ICT) that has emerged nowadays plays a major role in globalization, where national boundaries are blurred by instant communications, communication and even sharing of information (Cohen, 2009), (Habiburrahim, 20I5).

The world's borders seem to be reduced in this global age. Other people living in other countries can easily know and perceive one activity that happens in a corner of a globe. Supported by various advanced technological technologies, a wealth of information, science, expertise, and other useful research findings and inventions can be accessed by people from different parts of the world, often from continents away. Besides, the Internet plays a paramount role in the educational environment. It is used as a class enhancement or as a vehicle for greater education, which is becoming increasingly popular. The Internet is now used in lecture halls, tutorials, laboratories, and in the preparation of assignments as a strong complement to the conventional forms students study and learn (Hammer \& Kellner, 200I). There is a very similar match between the structures and processes of the Internet and the teaching and learning structures and processes in the conventional forms of education at the University (Cohen, 2009), (Habiburrahim, 20I5).

Students need to be able to collect and use online information in a world that is increasingly adopting digital media as the principal means of communication. To learn to access the web objectively and effectively, they must be acquainted with the text formats encountered online. The typical texts encountered online involve certain processes of reading, such as determining the confidentiality of sources, drawing inferences from multiple texts, and navigating within and across pages, more than conventional printed texts do. Both of these processes can be learned and practised in school environments (OECD, 20I5).
Empowering young people to become full participants in today's digital public space, equipping them with the codes and tools of their technology-rich society, and enabling them to use online learning opportunities - all while exploring the use of digital technology to improve existing educational processes, such as student assessment or school administration - are goals that justify (OECD, 20I5).

The remarkable growth of advanced communication technologies has driven universities, businesses, and educational institutions into experimenting with alternatives to conventional teaching methods in classrooms (Favretto et al., 2003)[9]. ICT's growing pace and distribution already shows that our local universities and learning and science groups are no longer purely local, but have gone global (Beebe, 2004) (Nawaz \& Qureshi, 20I0).

\section{Concepts}

\section{Education, Teaching, and Technology}

Christensen, Horn, and Johnson (2008) cited in (Salavati, 2016) add that with educational goals in mind, emerging innovations were not invented (Salavati, 20I6). They argue that the modest influence that computers have had on how learners learn and teachers teach is due to the "perfectly linear, perfectly reasonable and perfectly incorrect" ways in which innovations are used in schools (Christensen, Horn \& Johnson, 2008, p.73). They argue that the modest effect that computers have had on how learners learn and teachers teach. Equally, Bates (2015) notes that schools and the way they currently do things are most frequently simply added to emerging technologies (Salavati, 2016). Christensen and colleagues (2008) add that the way technology is implemented into classrooms only slightly strengthens the way teachers teach and the way the school is run, never enabling schools to take full advantage of technologies (Salavati, 2016).

\section{ICT}

Information and Communication Technology is a truncation, which means "Information and Communication Technology" ICTs are a paragliding concept that combines all developments for all digital data management and communication. ICT finds all current computerized programming vocations to support individuals, companies, and organizations as of 
now. ICT is difficult to depict because it is hard to keep up with the motions that happen so quickly. ICT is a matter of restricting, extracting, handling and transmitting computerized data. It can be identified as processing and communication agencies and highlights that differently support educational instruction, learning, and exercise scope (Nawaz \& Qureshi, 2010), (Suleiman et al., 2020).

Thomas cited in (Madlela, 20I5) Claims that Information and Communication Technology is frequently used as an extended synonym for information technology (IT), but is a more precise concept that emphasizes the role of unified communications and the integration of telecommunications, telephone lines, and wireless signals, computers as well as required business applications, middleware, storage, and audiovisual systems, allowing them to be integrated. Oliver (3), on the other hand, argues that the term ICT is now also used to refer to the convergence of audiovisual and telephone networks with computer networks through a single cable or connection system (Nawaz \& Qureshi, 20I0), (Madlela, 20I5).

\section{Digital Education}

Digital education also referred to as Technology Enhanced Learning (TEL) or elearning, is the creative use of digital resources and innovations while teaching and learning. Exploring the use of emerging technology offers teachers the ability in the classes they offer to design interactive learning environments, which can take the form of mixed or entirely online programs and courses (Delgado Kloos et al., 2017), (Banerjee et al., 2015), (Celeste McLaughlin, 2018).

\section{Virtual Learning}

Virtual Learning (VL) dated back to I840, when Sir Isaac Pitman, the English inventor of shorthand, came up with the idea of delivering instruction via correspondence courses by mail. But only with the advances of modern technology has distance education grown to a multibilliondollar market (Dinevski \& Kokol, 2005). Virtual University (VU) at vu.edu.pak is the best example of virtual learning with zero-physical contact but virtually 100percent connected with its eStudents. The VU is a 'university without walls', an unpacked virtual institution thus 'The University' as an institution, seizes to exist.
Where content and instructions are delivered through the Internet, intranet, extranet, satellite TV, and CD-ROM with multimedia capabilities (Manochehr, 2007). The university, then, becomes far more externally oriented; an intermediary on the global stage, acting as a collaborator, client, contractor, and broker of higher education services (Goddard \& Cornford, 2007), (Kundi \& Nawaz, 20I4), (Delgado Kloos et al., 2017), (Banerjee et al., 20I5).

\section{Online Learning}

Online learning is highly versatile, allowing you to research around your busy schedule conveniently. The bulk of our learners also work when they research with us digitally (Banerjee et al., 20I5), (Celeste McLaughlin, 20I8).

\section{Blended Learning}

Blended techniques use different techniques to provide learning that incorporates face-to-face experiences with online activities. In short, the alignment between the elements of the classroom and the operation that is digitally activated differs based on the learning formulation and construction. The versatility inherent in this type of delivery allows instructors to rethink where and how they concentrate educational process and learners to build selfdirected learning skills and electronic literacies (Delgado Kloos et al., 2017), (Banerjee et al., 20I5), (Celeste McLaughlin, 20 I8).

\section{Potential Opportunities for Digital Education}

Rather than anything else, education influences the prospects of a nation for human growth and competitiveness. Fortunately, in education, the knowledge revolution provides some exceptional opportunities. Common sense teaches us that different learners should be trained differently by us. Parents show this innate insight as they interact with their children differently according to their unique ages (Dinevski \& Kokol, 2005). Universities and even smaller corporate divisions are being able to afford integrated digital systems (Ezziane, 2007) cited in (Kundi \& Nawaz, 20I4).

a) Enhancing Teaching \& Learning: For all of our children and young people, digital technologies will enrich the learning experience. From consultation activities, we know that our students are already highly exposed to digital technology and will 
support its expanded use as part of their education (Scottish Government \& APS Group Scotland., 2016), (Education in Digital Age: Opportunities and Threats, 1994), (Nawaz \& Qureshi, 2010), (Salavati, 2016), (The Scottish Government, 20I5).

b) Increasing ROI From K-I 2 and Higher Education: Although the United States spends more of its GDP on education than other OECD nations, in terms of reaping the benefits of that investment, it does not rank among the top 10 (Banerjee et al., 20I5), (Burkholder, n.d.).

c) Innovation Imperative in A Global and Competitive Workplace: Economic indicators, particularly in the United States' high-wage industries, have led towards a decline in jobs and new firm growth. The competitive effect of a working environment compounds these trends. As shown by the life sciences industry, innovation and entrepreneurship are important to driving job creation (Banerjee et al., 20I5), (Burkholder, n.d.).

d) Enhancing Parental and Students Engagement: There is promising evidence that the use of digital equipment and software for direct communication with parents would improve compliance with teacher demands for involvement, behaviour, and learning support among learners (The Scottish Government, 20I5), (Banerjee et al., 20I5).

e) Increasing Student Enrichment: For learners using innovation, the K-I 2 learning process may be more relevant, engaging, and interactive (Burkholder, n.d.).

f Mitigating Inequality: For many highpoverty, rural, urban and many other underserved learners who may not otherwise have access to these essential resources, designing an innovation-enriched curriculum will provide enhanced learning opportunities (Burkholder, n.d.).

g) Anywhere, Anytime \& Any Place: 24/7, the Virtual Classroom is accessible. Another strength brought about by the online learning format is time quality. Asynchronous communication via online conference programs enables the job, family, and study schedules of professional juggling to participate in class discussions (ION Professional Elearning Programs, 2020).

Threats and Challenges of Digital Education

Although digital education has important strengths and provides unique access to quality education, the use of this platform has limitations that can pose potential challenges to the success of any online courses (Kundi \& Nawaz, 20I4), (ION Professional Elearning Programs, 2020).

a) Computer Literacy: To work effectively in an online environment, both students and intermediaries must possess a basic level of computer literacy. They need to be able to use a range of search engines, for example, and to access the World Wide Web easily, as well as to be familiar with newsgroups, FTP procedures, and e-mail. They cannot excel in an online program if they do not have these technological tools; a student or faculty member who cannot work on the system can pull the whole program down (ION Professional Elearning Programs, 2020).

b) Lack of Teacher-Student Physical Interaction: How much teacher contact learners get on a physical campus is easy to underestimate. Then there is the instruction time itself, with the question-and-answer in real-time. Then right before and after training, once hours, chance encounters in the corridor, there is an opportunity for discussion ... all possibilities that are not accessible for digital education (Kundi \& Nawaz, 20l4), (Banerjee et al., 20I5), (Courses, 2019).

c) Need for Self-Discipline: In a tertiary education classroom environment, many students struggle with self-discipline. They don't have parents and teachers constantly checking in for the remainder of their time. If they miss homework to go socialize, they don't get grounded. It takes time for others, and the intrinsic drive to buckle down and do the job. It's even easier to "skip class" or place an assignment on an online course (Courses, 2019).

d) Technological Difficulties: We prefer to take it for granted that a laptop or desktop computer of the latest model is available to everyone. Not every student has had the 
same access to technology, however, even for a generation of digital natives. For all their online operation, many rely on their smartphone or a tablet. Some would have restricted broadband or Wi-Fi connectivity, even though all their information comes from their phone plan (ION Professional Elearning Programs, 2020), (Cunha et al., 2020), (Courses, 2019).

e) Poor Time Management: This challenge is connected to the aspect of self-discipline, but it deserves its entry. One of the main benefits of this approach is that students can learn at their speed. The profit can also be a liability, however. At the end of the term, there is a point at which "their own pace" becomes "procrastination and a crazy scramble." It is necessary to help students maintain their pace well before the deadline reach (Courses, 2019), (Cunha et al., 2020).

f) Digital Education is not suitable for Practical Courses: For practical activities in tertiary education, digital and e-learning are incompatible. E-learning offers realistic session-related knowledge and preparation, but instead of mastering preparing, the learner does not measure their output or real-time experience. Knowing things and moving them in an unsystematic way is pointless (Naresh \& Rajalakshmi M., 2017), (Cunha et al., 2020).

g) Transmitting virus: These programs attach themselves to a file and then circulate. They usually affect the data on a computer, either by altering or deleting it (Suleiman, Muhammad Muhammad Anas, Abubakar Abdurrahman Jafaru, 2020)

\section{CONCLUSION}

Many countries have responded to rapid technological change by reshaping school education to develop learners' capacities for working with data and computation. Despite the present situation, many nations' curriculum now lags behind digital education.

\section{Acknowledgment}

We are grateful to our teachers and senior colleagues who are helping us in one way or another to make an effort to the realization of this piece of the article.

\section{REFERENCES}

Banerjee, P. M., Belson, G., \& Clugston, D. (20I5). Digital Education 2.0: From Content to Connections. Deloitte Review DELOIT, 16 , I30-145. https://dupress.deloitte.com/content/dam/du p-us-en/articles/future-digital-educationtechnology/DR I6_digital_education_2.0.pdf

Burkholder, K. (n.d.). Digital Learning: Meeting the Challenges and Embracing the Opportunities for Teachers. CED TASA, A Policy Brief from the Committee for Economic Development, Texas Association of School Administrators \& Fort Worth Chamber of Commerce.

Celeste McLaughlin. (20I8). What is digital education? INSTITUTE FOR ACADEMIC DEVELOPMENT (INSTITUTEACADEMIC-DEVELOPMENT), University of Edinburgh. https://doi.org//0.13 |40/RG.2.I.34|2.2960

Cohen, J. (2009). Diverting the radicalization track - Promoting alternatives among the Middle East's youths. In Hoover Institution Policy Review (Issue I54).

Courses, C. (2019). Digital Learning: 5 Challenges and How to Solve Them. Caduceus International Publishing Provides TopQuality Interactive Health Science Curriculum to Colleges, Universities and Institutions Wherever They Are Needed. https://www.cipcourses.com/resources/digita I-learning-challenges

Cunha, M. N., Chuchu, T., \& Maziriri, E. T. (2020). Threats, challenges, and opportunities for open universities and massive online open courses in the digital revolution. International Journal of Emerging Technologies in Learning, I5(12), 191-204. https://doi.org/I0.399I/ijet.vI5il 2.13435

Delgado Kloos, C., Rodriguez, P., VelazquezIturbide, A., Gil, M. C., Fernandez-Manjon, B., \& Tovar, E. (20I7). Digital education in the classroom. IEEE Global Engineering Education Conference, EDUCON, November, $\quad 31-32$. https://doi.org/10.I I09/EDUCON.2017.7942 818

Department for Education. (2019). Realising the potential of technology in education. A Strategy for Education Providers and the 
Technology Industry. https://doi.org/DFE00072-2019

Habiburrahim, H. (20I5). The Internet and ICT: Opportunities or Threats to the Education World? Englisia Journal, 3(I), I-8. https://doi.org/I 0.22373/ej.v3il.533

ION Professional Elearning Programs. (2020). Strengths and Weaknesses of Online Learning. University of Illinois. http://www.ion.uillinois.edu/resources/tutori als/overview/strengthAndWeak.asp

Kundi, G. M., \& Nawaz, A. (20|4). From eLearning 1.0 to e-Learning 2.0: Threats \& Opportunities for Higher Education Institutions in the Developing Countries. European Journal of Sustainable Development, 3(I), 145-160. https://doi.org//0.|4207/ejsd.20 I4.v3n Ip|45

Madlela, B. (20I5). ICT Opportunities and Threats in Implementing Teaching Practice Programmes. Universal Journal of Educational Research, 3(6), 35I-358. https://doi.org/I0.13189/ujer.2015.03060I

Makosa, P. (20I4). Advantages and disadvantages of digital education. October 2013.

Naresh, B., \& Rajalakshmi M. (20I7). E-Learning in India: A SWOT Analysis. International Journal of Engineering Technology Management and Applied Sciences2, 5(I0), 2349-4476.

Nawaz, A., \& Qureshi, Q. A. (2010). Eteaching/Epedagogy Threats \& Opportunities for Teachers in Heis. Global Journal of Management and Business Research, 10(9), 23-3I. https://journalofbusiness.org/index.php/GJMB $\mathrm{R} /$ article/view/28 I

OECD. (2015). Implications of Digital Technology for Education Policy and Practice. In Students, Computers and Learning Making the Connection, OECD Publishing, Paris. https://doi.org/I0.1787/9789264239555-II-

en

Education in Digital Age: Opportunities and Threats, (1994).

Salavati, S. (2016). Use of Digital Technologies in Education: The Complexity of Teachers' Everyday Practice. Linnaeus University Dissertations No 264/2016. https://doi.org// 0.1787/9789264265097-5-en Scottish Government, \& APS Group Scotland.
(20I6). Enhancing Learning and Teaching through the use of Digital Technology: A Digital Learning and Teaching Strategy for Scotland.

https://www.gov.scot/binaries/content/docu ments/govscot/publications/strategyplan/2016/09/enhancing-learning-teachingthrough-use-digitaltechnology/documents/00505855pdf/00505855-

$\mathrm{pdf} /$ govscot\%3Adocument?forceDownload=t rue

Suleiman, Muhammad Muhammad Anas, Abubakar Abdurrahman Jafaru, A. (2020). The Concept and Scope of Cybercrimes. International Journal of Research, 7(6), II8129.

https://journals.pen2print.org/index.php/ijr/

Suleiman, M. M., Yahya, A. T., \& Tukur, M. (2020). Effective Utilization of ICT Tools in Higher Education. Journal of Xidian University, 14(9), 588-594. https://doi.org/https://doi.org//0.37896/jxul4 $.9 / 061$

The Scortish Governemnt, I. C. S. L. (20I5). Literature Review on the Impact of Digital Technology on Learning and Teaching Children, Education and Skills. Social Research Series. http://www.gov.scot/Resource/0048/004892 24.pdf 